\title{
OD MOŻLIWOŚCI DO IMPERATYWU: HISTORIA RYNKU
}

\author{
ELLEN MEIKSINS WOOD
}

PRZELOŻYL: MichA£ CHOTKIEWICZ

\begin{abstract}
Abstrakt: Autorka pokazuje w swoim artykule, że historia kapitalistycznego rynku nierozerwalnie wiąże się $\mathrm{z}$ bezprecedensowym w historii użyciem siły i przemocy. Takie konsekwentne spojrzenie na rynek pozwala inaczej interpretować przejście z porządku feudalnego do kapitalistycznego. Autorka wskazuje, że nie było ono „wyzwoleniem” spod feudalnych okowów, ale przeciwnie - wiązało się z podporządkowaniem rynkowym imperatywom produkcji kapitalistycznej, które wynikało nie tyle z technologicznego postępu czy nieomal ponadhistorycznych praw, ale z przekształceń społecznych stosunków własności między chłopami a panami w Anglii. Proponowane w artykule ujęcie kapitalistycznego rynku stawia też w innym świetle przeciwstawione mu alternatywy polityczne.
\end{abstract}

Słowa kluczowe: kapitalizm, rynek, historia, Brenner, Polanyi. 
Praktycznie każda słownikowa definicja „rynku” wiąże go z możliwościq: rynek jako konkretne miejsce lub instytucja przekłada się na możliwość kupna i sprzedaży, natomiast jako abstrakcja oznacza możliwość sprzedaży ${ }^{1}$. Często można usłyszeć, że dobra „znajdują swój rynek”, a gdy istnieje na nie popyt, mowa o rynku dla danego towaru albo usługi, co znaczy, że moga być one sprzedane. Rynki są otwarte dla tych, którzy chcą coś sprzedać. Rynek stanowi „warunki, które tyczą się możliwości kupna i sprzedaży” (The Concise Oxford Dictionary); oznacza oferte i wybór.

Czym są zatem sity rynkowe? Czy siła nie oznacza przymusu? W klasycznym języku kapitalistycznej ideologii rynek nie oznacza przymusu, ale wolność. Jednocześnie wolność ta jest gwarantowana przez pewne mechanizmy regulacyjne. Dzięki wolności wyboru zapewniaja one racjonalna gospodarkę, w której podaż zaspokaja popyt. Mechanizmy te są bezosobowymi „siłami” rynku i, jeżeli są w jakimś sensie w ogóle przymusowe, to w tym, że zmuszaja ekonomicznych aktorów do „racjonalnego” działania w celu maksymalnego zwiększenia wyboru i możliwości.

Wszystko to zmierza do stwierdzenia, że kapitalizm jako ostateczne „społeczeństwo rynkowe" stwarza optymalne warunki wyboru i [realizacji] możliwości. Oferuje on coraz więcej dóbr i usług, co przekłada się na rosnącą liczbę osób cieszących się swobodą ich sprzedaży i czerpania z nich zysku oraz przyrost ludzi, którzy mogą spośród nich wybierać i je kupować.

Co jest więc nie tak $z$ tym wyobrażeniem? Socjalista odpowiedziałby pewnie, że pominięto tu przede wszystkim utowarowienie siły roboczej i wyzysk klasowy. Niech tak będzie. Ale to, co nie zawsze wybrzmiewa dość głośno, nawet w lewicowych koncepcjach rynku, to fakt, że głównym i wyróżniającym elementem kapitalistycznego rynku nie jest możliwość ani wybór, ale coś wręcz przeciwnego - przymus. W kapitalizmie materialne warunki życia i reprodukcja społeczna są w każdym aspekcie zapośredniczone przez rynek, a zatem wszystkie jednostki muszą nawiązywać stosunki rynkowe w celu zdobycia dostępu do podstawowych dóbr zapewniających utrzymanie. Dyktaty kapitalistycznego rynku - jego imperatywy konkurencji, akumulacji, maksymalizacji zysku i zwiększania produktywności pracy - regulują nie tylko wszelkie stosunki ekonomiczne, ale też stosunki społeczne w ogóle. Ponieważ relacje pomiędzy jednostkami są zapośredniczane w procesie wymiany towarowej, to międzyludzkie stosunki społeczne zdają się być relacjami między rzeczami, co Marks określił słynnym mianem „fetyszyzmu towarowego”.

Niektórzy czytelnicy zapewne zaprotestuja, że nie jest to nic, czego nie wiedziałby każdy socjalista, a już na pewno marksista. Mam jednak co do tego wątpliwości. Twierdzę, co zaraz

\footnotetext{
1 Niniejszy artykuł ukazał się pierwotnie w Monthly Review 1994, 46 (3) (https://archive.monthlyreview.org/ index.php/mr/article/view/MR-046-03-1994-07_2/). Meiksins Wood była wspólwydawczynią oraz stale publikującą autorką tego pisma. Prawa do jego polskiego tłumaczenia zostały nieodpłatnie udostępnione redakcji Prak.tyki Teoretycznej dzięki uprzejmości redaktorek Monthly Review (przyp. tłum.).
} 
udowodnię, że większość ujęć historii kapitalizmu, zarówno lewicowych jak i prawicowych, nie dostrzegała jego historycznej specyfiki - osobliwości kapitalistycznego rynku jako opartego raczej na przymusie niż swobodzie. Uważam, że na nasze współczesne rozumienie kapitalizmu oraz horyzontu politycznych możliwości socjalistycznej alternatywy wpływa na to, jak rozumiemy jego historię: w jaki konkretnie sposób przedstawia on historyczne zerwanie z wcześniejszymi formami społecznymi i co nam to mówi o specyfice kapitalistycznego rynku.

\section{I}

Większość klasycznych teorii kapitalizmu nie chce przyznać, że rynek stał się kapitalistyczny dopiero, gdy został oparty na praymusie. Sugerują one raczej, że wspomniany system pojawia się wraz z wyzwoleniem rynku $\mathrm{z}$ wielowiekowych ograniczeń oraz powodowanym przez szereg czynników wzrostem możliwości handlu. Kapitalizm wiązany jest wobec tego nie tyle $z$ radykalnym zerwaniem $z$ poprzednimi formacjami, ale raczej $z$ potężnym ilościowym wzrostem, poszerzaniem się rynków i rosnącą komercjalizacją życia gospodarczego. Poniżej przedstawię tradycyjne ujęcie, które przewija się w klasycznej ekonomii politycznej, oświeceniowych teoriach postępu i wielu innych nowożytnych historiach.

Racjonalne, egoistyczne jednostki, które mają skłonność do, jak ujął to Adam Smith, „wymiany, handlu i zamiany jednej rzeczy na drugą”, parały się wymianą już od zarania dziejów. Wraz z rozwijającym się podziałem pracy postępowała specjalizacja wymiany, czemu towarzyszyło techniczne ulepszanie środków produkcji (w wielu z tych wyjaśnień ulepszenia w produktywności mogły być w istocie fundamentalnym celem zwiększającego się, wyspecjalizowanego podziału pracy, co pokazuje bliski związek między tymi teoriami a pewnego rodzaju determinizmem technologicznym). W rezultacie kapitalizm (lub „społeczeństwo handlowe”, które jest najwyższym etapem jego postępu) jawi się jako rezultat dojrzewania wielowiekowych praktyk handlowych oraz efekt ich wyzwolenia spod politycznych i kulturowych ograniczeń.

Owe ograniczenia miały być jednak w pełni zniesione jedynie na Zachodzie. W starożytnym, śródziemnomorskim „społeczeństwie handlowym” rynek był już całkiem nieźle ugruntowany, ale jego dalszy rozwój został zakłócony przez nienaturalną przerwę. Stały za nią feudalne skostnienie i kilka wieków „ciemnych”, kiedy to życie gospodarcze znów zostało spętane przez irracjonalizm i polityczne pasożytnictwo cechujące władzę właścicieli ziemskich. Klasyczne wyjaśnienie tej przerwy odwołuje się do „barbarzyńskich” najazdów na Imperium Rzymskie. Późniejsza i bardzo wpływowa wersja tego modelu (rozwijana od lat dziewięćdziesiątych dziewiętnastego aż do lat dwudziestych dwudziestego wieku przez belgijskiego historyka Henriego Pirenne’a) sytuuje zerwanie ze śródziemnomorska cywilizacją handlową później - w muzułmańskiej inwazji, która ograniczyła stary system handlowy przez 
zamknięcie śródziemnomorskich szlaków między Wschodem a Zachodem (zob. np. Pirenne 1952). Rozwijająca się „ekonomia wymiany”, na czele której stała profesjonalna klasa kupiecka, została wtedy zastapiona przez „ekonomię konsumpcji”, czyli rentierską ekonomię feudalnej arystokracji.

Jednak ostatecznie, zarówno według Pirenne’a, jak i jego poprzedników, handel ożywił się wraz z rozwojem miast i wyzwoleniem kupców. Pojawiły się ośrodki o wyraźnej i bezprecedensowej autonomii - miasta handlowe zdominowane przez autonomiczną klasę mieszczańską, która miała raz na zawsze wyzwolić się z okowów starych ograniczeń kulturowych i politycznego pasożytnictwa. To uwolnienie gospodarki miejskiej, działalności handlowej i merkantylnej racjonalności (wraz z nieuniknionymi ulepszeniami w technikach produkcji, które ewidentnie wynikały z uwolnienia handlu) okazało się wystarczającym czynnikiem, ażeby wyjaśnić powstanie nowoczesnego kapitalizmu.

Były też inne próby udoskonalenia starego „modelu handlowego” - podejmowane od czasów Webera aż po Braudela². Pojawiły się również frontalne ataki na sam „model handlowy”, a zwłaszcza tezę Pirenne’a (współcześnie powszechnie odrzucana). Obecnie najbardziej wpływowym i niemal hegemonicznym stał się model demograficzny, który wiąże europejski rozwój gospodarczy z określonymi, autonomicznymi cyklami wzrostu i spadku liczby ludności. Pomimo tego, że stary model został radykalnie zakwestionowany, jego fundamentalne założenia wydają się wciąż pozostawać nietknięte. W taki lub inny sposób, czy to poprzez wskazanie na procesy urbanizacji i rozwoju handlu, czy też odwołanie do cyklicznych modeli wzrostu demograficznego, wszystkie przywołane wyjaśnienia przejścia do kapitalizmu opieraja się na powszechnych i ponadhistorycznych prawach rynku: prawach popytu i podaży (zob. Brenner 1985, 10).

Pojawia się tu oczywiście istotny paradoks. Koncepcję rynku jako areny wyboru i „społeczeństwa handlowego" jako ideału wolności wiązano zazwyczaj z teoria historii, zgodnie z którą współczesny kapitalizm był rezultatem niemal naturalnego procesu wynikającego z powszechnych, ponadhistorycznych i niezmiennych praw. Możliwe jest przynajmniej na pewien czas - wstrzymanie ich działania, wiąże się to jednak z dużymi kosztami. „Wolny” rynek traktowany jako efekt tych praw okazuje się bowiem bezosobowym mechanizmem, który wprawdzie można do pewnego stopnia kontrolować i regulować, ale grozi to niepotrzebnym niebezpieczeństwem związanym z każdą próbą naruszania praw naturalnych.

\footnotetext{
2 Związki Webera z omawianym modelem omawiam w: Meiksins Wood 1994.
} 
Wszystkie te wyjaśnienia wychodzą ze wspólnego założenia o ciagłości handlu i rynków - od ich najwcześniejszych przejawów w postaci pierwotnej wymiany aż do ich dojrzałości osiagniętej we współczesnym kapitalizmie przemysłowym. Wielowiekowa praktyka handlarskiego czerpania zysków, którą ujęto w maksymie: „kup tanio, sprzedaj drogo”, nie jest według tych modeli zasadniczo różna od kapitalistycznej wymiany i akumulacji przez przywłaszczenie wartości dodatkowej. Oczywiście nastapiło istotne przejście od feudalizmu do kapitalizmu, ale transformacja ta nie dotyczyła samej istoty handlu i rynków. Zmiana polegała raczej na tym, co stało się z siłami i instytucjami (politycznymi, prawnymi, kulturowymi, ideologicznymi i technologicznymi), które przeszkodziły naturalnej ewolucji handlu i dojrzewaniu rynków.

To właśnie w tych modelach, jeśli gdziekolwiek, feudalizm reprezentuje rzeczywiste historyczne zerwanie. Wznowienie handlowego rozwoju, poczynając od szczelin w ramach feudalizmu, a następnie przechodząc do przełamania jego ograniczeń, jest z pewnością traktowane jako istotna zmiana w historii Europy. Wydaje się to czymś w rodzaju korekty kursu procesu historycznego, który to tymczasowo - nawet jeśli drastycznie i przez długi czas - został zepchnięty z właściwej drogi. Założenia te mają jeszcze inne ważne następstwo. Chodzi tu o to, że miasta i handel były z natury przeciwne feudalizmowi, zatem ich rozwój, jakkolwiek by do niego nie doszło, podważał podstawy tego systemu.

Ale nawet jeśli feudalizm zgodnie z tymi wyjaśnieniami zakłócił postęp społeczeństwa handlowego, to wciąż nie zmienił on wewnętrznej logiki rynku. Rynek od zarania miał angażować racjonalne, egoistyczne jednostki, które, gdy tylko pojawiała się taka możliwość, maksymalizowały użyteczność poprzez sprzedaż towarów dla zysku. W szczególności dotyczyło to rosnącego podziału pracy i specjalizacji, które wymagały coraz bardziej rozbudowanej sieci handlowej, a przede wszystkim nieustannego polepszania technik produkcyjnych mających obniżyć koszty w celu zwiększenia zysków handlowych. Można na różne sposoby ograniczać działanie tej logiki, w istocie pozostaje ona jednak każdorazowo taka sama. Zawsze otwiera możliwości, za każdym razem sprzyja wzrostowi gospodarczemu i ulepszeniu sił wytwórczych i niezmiennie, jeżeli pozostawić ja samej sobie, w naturalny sposób doprowadzi do kapitalizmu przemysłowego.

Nie dostrzega się tutaj specyficznych dla kapitalizmu imperatywów, osobliwych sposobów funkcjonowania rynku w kapitalizmie, charakterystycznych praw ruchu, które jednoznacznie zmuszają ludzi do wejścia na rynek, a wytwórców do wydajnej produkcji poprzez zwiększanie produktywności pracy - słowem prawa konkurencji, maksymalizacji zysku i akumulacji kapitału. Wynika z tego, że zgodnie z tymi modelami nie ma potrzeby wyjaśnienia konkretnych społecznych stosunków własności i specyficznego reżimu wyzysku, który określa 
te prawa ruchu. Nie ma w istocie potrzeby wyjaśnienia powstania kapitalizmu, ponieważ zakłada się, że istnieje on, choćby w formie embrionalnej, od zarania dziejów (o ile nie u samych źródeł natury i ludzkiej racjonalności). Ludzkość, o ile są ku temu odpowiednie warunki, nie jest związana ograniczeniami instytucjonalnymi lub kulturowymi - zawsze działała zgodnie z regułami kapitalistycznej racjonalności poprzez dążenie do zysku, szukając jednocześnie sposobów na zwiększenie produktywności pracy. Historia toczy się zatem za sprawą wzrostu gospodarczego i zgodnie z prawami rozwoju kapitalistycznego, który jest zapewniony przez rozkwit sił wytwórczych (aczkolwiek z pewnymi istotnymi przeszkodami). Jeżeli powstanie dojrzałej gospodarki kapitalistycznej wymaga w ogóle wyjaśnienia, to tylko w stosunku do istnienia barier, które uniemożliwiały jej rozwój, i procesu, dzięki któremu zostały one zniesione.

\section{III}

Jeden z najważniejszych przykładów przełamania tej narracji daje historyk gospodarczy i antropolog Karl Polanyi. Zarówno w swoim klasycznym dziele, Wielkiej transformacji (opublikowanej po raz pierwszy w 1944 roku), jak i w innych pracach twierdzi on, że motyw indywidualnego zysku związanego z wymiana rynkową nie był nigdy - aż do epoki nowoczesnej - dominująca zasadą rzeczywistości ekonomicznej. Pisze również o tym, że nawet tam, gdzie rynki były dobrze rozwinięte, należy dokonać ostrego rozróżnienia na opierające się na nich społeczeństwa (istniejące w całej odnotowanej dotychczas historii) i [nowoczesne] „społeczeństwo rynkowe”. We wszystkich wcześniejszych społeczeństwach stosunki i praktyki „ekonomiczne” były „zakorzenione” albo zanurzone w nieekonomicznych stosunkach społecznych, takich jak różnego rodzaju więzi rodowe, wspólnotowe, religijne i polityczne. Istniały też inne motywacje dla działalności gospodarczej niż czysto „ekonomiczna” chęć zysku czy korzyść materialna - mogło być to np. osiaganie statusu i prestiżu lub utrzymanie wspólnotowej solidarności. Funkcjonowały też inne sposoby organizacji życia gospodarczego w odróżnieniu od mechanizmów wymiany rynkowej; zwłaszcza to, co Polanyi określa zasadą „wzajemności” i „redystrybucji”.

Tylko w nowoczesnym „społeczeństwie rynkowym”, argumentował autor Wielkiej transformacji, istnieje odrębny motyw „ekonomiczny” i mamy tam do czynienia z instytucjami oraz stosunkami ekonomicznymi, które są oddzielone od tych nieekonomicznych. Z uwagi na to, że istoty ludzkie oraz natura (w formie pracy i ziemi) traktowane sa jako towary fikcyjne w samoregulującym się systemie rynków, który opiera się na mechanizmie cenowym, samo społeczeństwo staje się „dodatkiem” do rynku. Gospodarka rynkowa może istnieć tylko w społeczeństwie rynkowym, czyli takim, w którym zamiast gospodarki opartej na stosunkach społecznych to te ostatnie sa zakorzenione w gospodarce. 
Polanyi wprost zakwestionował założenia Adama Smitha o „człowieku ekonomicznym” i jego naturalnej „skłonności do wymiany, handlu i zamiany jednej rzeczy za druga” (Polanyi 2010, 53). Twierdził on, że „skłonność” ta nie tylko nie odgrywała (aż do czasów Smitha) przypisywanej jej dominującej roli, ale aż do następnego stulecia nie regulowała ona gospodarki. Rynki, które istniały w czasach społeczeństw przedrynkowych, nawet jeśli osiagały spore rozmiary i znaczenie, były podrzędnym elementem gospodarki, który podporządkowywał się innym zasadom działania ekonomicznego. Co więcej, rynki te, nawet w postaci najbardziej rozległych i złożonych systemów handlowych, działały na podstawie zupełnie innej logiki niż ta właściwa dla współczesnego rynku kapitalistycznego.

Polanyi opowiadał się w szczególności za tym, że ani rynki lokalne, ani handel dalekosiężny (oba charakterystyczne dla gospodarek przedkapitalistycznych), nie były w swojej istocie konkurencyjne. Handel zagraniczny opierał się po prostu na „przewozie”. Zadaniem kupca było tu przetransportowanie dobra z jednego rynku na drugi. Natomiast w handlu lokalnym działalność handlowa była ściśle regulowana i ograniczona. Ogólnie rzecz biorąc, konkurencja była stamtąd celowo eliminowana, gdyż destabilizowała handel.

Pozwolę sobie tutaj wyjaśnić kilka kwestii, które moga nie być dostatecznie jasne w koncepcji Polanyiego. Weźmy na przykład handel dalekosiężny, czyli szczególną formę działalności ekonomicznej warunkująca powstanie wielkich ośrodków handlowych, które zgodnie ze wszystkimi wersjami modelu handlowego stanowią zapowiedź kapitalizmu. Ten rodzaju handlu przybrał formę „handlowego arbitrażu pomiędzy wyodrębnionymi rynkami” (Kerridge 1985, 4). Zasada działania było tutaj kupowanie tanio na jednym rynku i droga sprzedaż na innym, a nie konkurencja w obrębie jednego, zintegrowanego rynku. Jeżeli istniała w ogóle jakaś konkurencja, to nie opierała się ona na wydajności produkcji, a z cała pewnością nie była ona motorem całej gospodarki. Zasadniczo to warunki „pozaekonomiczne” - takie jak dominacja na morzach i innych szlakach transportowych albo wysoko rozwinięte instytucje finansowe i instrumenty arbitrażu - były kluczem do przewagi handlowej. Tego typu handel, zwłaszcza ten nastawiony na wąski rynek dóbr luksusowych, nie wywołuje impulsu do zwiększania produktywności. Powołaniem dużego kupca była raczej cyrkulacja aniżeli produkcja. I nawet wtedy, gdy główne ośrodki handlowe (takie jak Florencja) rozwijały wewnętrzna produkcję, która wykraczała poza jej funkcje służebne wobec zewnętrznej działalności handlowej, zasadnicza logika transakcji ekonomicznych w istocie się nie zmieniła. Dla kupca była to dalej raczej kwestia ograniczonej produkcji na rynek dóbr luksusowych i obiegu bogactwa w procesie cyrkulacji niż wytwarzania wartości w produkcji i jej zawłaszczania przez zwiększanie wartości dodatkowej na modłę kapitalistyczna.

Polanyi wskazuje, że tylko narodowe rynki wewnętrzne (ukształtowane bardzo późno wobec dużego oporu ze strony kupców i autonomicznych miast najlepiej rozwiniętych regionów handlowych w Europie) opierały się na zasadach konkurencji. Ale nawet rynki 
wewnętrzne w ramach wczesnonowożytnych państw narodowych były przez pewien czas tylko luźnym amalgamatem odrębnych rynków miejskich, które wiązały wspólne przedsięwzięcia handlowe (niewiele różniące się od dalekosiężnego handlu zamorskiego). Zintegrowany rynek wewnętrzny nie był też ani bezpośrednim następca, ani rezultatem naturalnej ewolucji, której podlegałby poprzedzający go handel lokalny lub dalekosiężny. Był raczej, jak twierdzi Polanyi, wytworem interwencji państwowej, ale nawet wówczas (mówimy tu bowiem o gospodarce, która opierała się w znacznej mierze na produkcji zachodzącej na gruncie samowystarczalnych i wytwarzających dla własnych potrzeb gospodarstw chłopskich) regulacja państwa nadal dominowała nad zasadami konkurencji.

O kwestii wewnętrznego, konkurencyjnego rynku i warunków, w których powstał, będzie jeszcze mowa poniżej. Teraz chciałabym przez moment skupić się na szczególnie istotnych elementach w koncepcji rynku Polanyiego. Autor Wielkiej transformacji nie był oczywiście jedynym badaczem, który dostrzegal wtórną rolę rynku w społeczeństwach przedkapitalistycznych. Każdy kompetentny historyk gospodarczy czy antropolog musi uznać istnienie rozmaitych nierynkowych reguł działania ekonomicznego, które funkcjonowały w społeczeństwach: od najbardziej „,pierwotnych” i egalitarnych aż po najbardziej złożone, rozwarstwione i oparte na wyzysku, „wysokie” cywilizacje. I to właśnie tacy historycy (aczkolwiek nie tak wielu, jak mogłoby się wydawać) dostrzegli pewne zmiany w funkcjonowaniu handlu. Koncepcja Polanyiego jest jednak szczególnie godna uwagi ze względu na bardzo trafny opis zerwania, do którego doszło między „społeczeństwem rynkowym" a poprzedzającymi je społeczeństwami nierynkowymi (włącznie z tymi, które dorobiły się rynków). Miało ono miejsce nie tylko z uwagi na różnice w ich ekonomicznych logikach, ale także ze względu na społeczną destabilizację, które niosła ze sobą ta transformacja. Polanyi podkreślał, że system samoregulujących się rynków był na tyle niszczący - nie tylko dla stosunków społecznych, ale również ludzkiej psyche - a jego rezultaty tak koszmarne dla ludzi, że historia jego urzeczywistniania musiała być równocześnie historią obrony przed jego skutkami, zwłaszcza w postaci podejmowanych w ramach interwencji państwa „środków zaradczych”, bez których „społeczeństwo zostałoby unicestwione” (Polanyi 2010, 92).

Argumenty Polanyiego radykalnie zrywaja zatem $\mathrm{z}$ tymi koncepcjami rozwoju gospodarczego, które podkreślaja (mniej lub bardziej korzystne) formy kontynuacji pomiędzy antycznym handlem a nowoczesną gospodarką kapitalistyczna, nawet wówczas gdy kładą nacisk na antagonizm pomiędzy „handlowymi” albo kapitalistycznymi regułami a ekonomiczna (albo antyekonomiczna) logiką feudalizmu. Jednak w kilku ważnych kwestiach jego koncepcja zdradza istotne pokrewieństwo z bardziej konwencjonalnymi historiami gospodarczymi.

Po pierwsze, w jego argumentacji zaskakująco istotną rolę odgrywa determinizm technologiczny. Głównym przedmiotem zainteresowania Polanyiego jest stworzenie społeczeństwa rynkowego przez rewolucję przemysłowa. Zajmuje go również przekształcenie 
„,człowieka i przyrody w towary” (Polanyi 2010, 51), które stało się w pewien sposób konieczne dzięki wynalezieniu skomplikowanych maszyn. „W związku z tym, że złożone maszyny są drogie”, czytamy w Wielkiej transformacji, „opłaca się w nie inwestować tylko pod warunkiem, że będa wytwarzały dużo towarów”. Zapewnienie nieprzerwanej produkcji wymaganej do osiagnięcia wystarczającej skali produkcji oznacza, że dla kupca „wszystkie elementy zaangażowane w proces produkcji muszą być w ciagłej sprzedaży" (Polanyi 2010, 50). Ostatecznym i najbardziej katastrofalnym krokiem w tworzeniu warunków koniecznych dla zaistnienia społeczeństwa rynkowego - którego powstanie było wymagane już wcześniej przez produkcję złożonych maszyn - było przekształcenie pracy w „czynnik” towarowy.

Kolejność przyczynowa jest tutaj znacząca. Rewolucja przemysłowa była „jedynie początkiem” „niezwykle głębokiej i radykalnej” rewolucji, która całkowicie przekształciła społeczeństwo poprzez utowarowienie człowieka i natury (Polanyi 2010, 49). Jej sercem był „nieomal cudowny postęp w dziedzinie narzędzi produkcji” (Polany 2010, 41), który spowodował przekształcenie społeczeństwa, stanowiąc kulminację wcześniejszych ulepszeń w produkcji (jej metod jak i organizacji uprawy ziemi - zwłaszcza grodzeń w Anglii). Chociaż Polanyi nie zgadza się z wiarą w „spontaniczny postęp”, to nigdy, nawet na moment, nie zdaje się wątpić w nieuchronność usprawnień - przynajmniej w kontekście zachodniego społeczeństwa handlowego z jego „wolnymi instytucjami”, a zwłaszcza wyzwolonymi wspólnotami miejskimi i ekspansją handlową; nie waţpi też w „wyraźnie obecną w ówczesnej Europie Zachodniej tendencję postępu gospodarczego” (Polanyi 2010, 45).

Istotne elementy historycznej narracji Polanyiego pod pewnymi względami nie odbiegają zatem tak bardzo od mniej krytycznych wersji modelu handlowego: ekspansja rynków następuje równolegle do technologicznego postępu, co prowadzi do powstania współczesnego kapitalizmu przemysłowego. Pomimo tego, że kulminacja owego procesu ma miejsce w Anglii, ma on charakter ogólnoeuropejski. Dlatego może się wydawać, że proces przechodzenia od komercjalizacji [gospodarki opartej na handlu] przez uprzemysłowienie do „społeczeństwa rynkowego" mógł w coraz bardziej merkantylnym świecie być mniej lub bardziej naturalna ewolucja, która dokonała się wyłącznie w Europie. I to jedynie dlatego, że na jej drodze po prostu nie pojawiły sie pewne nieekonomiczne przeszkody. Jak wyjaśniał na łamach Monthly Review jeden z uczniów Polanyiego (w swojej relacji z jego wykładów z „Powszechnej historii gospodarczej”), zdaniem autora Wielkiej transformacji zachodni feudalizm nie charakteryzował się [tak] silnymi więzami rodowymi, klanowymi i plemiennymi jak równie zmerkantylizowany Wschód, a zatem ,gdy osłabły i zniknęły więzi feudalne nic nie stało na przeszkodzie, by zapanowały nad nim siły rynkowe". I podczas gdy interwencja państwowa była potrzebna do stworzenia „czynników rynkowych”, to „rozwijająca się gospodarka rynkowa pomogła zniszczyć feudalne instytucje ekonomiczne i polityczne” (Fusfeld 1993, 6). 
Wyraźnie nie docenia się tutaj tego, że to radykalna transformacja stosunków społecznych poprzedzała industrializację, tworząc wyjątkowy na gruncie całej historii imperatyw ulepszania sił wytwórczych. Nie chcę przez to jedynie zarzucać Polanyiemu, że stawia wszystko na głowie. Ważniejszą kwestią jest to, że przyjęty przez niego porządek przyczynowy nie pozwala traktować samego kapitalistycznego rynku jako specyficznej formy społecznej. $\mathrm{W}$ istocie przy całym jego nacisku na społeczne skutki nowoczesnego rynku i sposoby, w jakie społeczeństwo zanurzyło się w gospodarce rynkowej (zwłaszcza na gruncie utowarowienia pracy), Polanyi nigdy nie traktuje samego rynku jako stosunku społecznego - czegoś odmiennego od bezosobowego mechanizmu, który nakłada się właśnie na tego rodzaju stosunki. Specyficzne imperatywy kapitalistycznego rynku - presja akumulacji i zwiększania produktywności pracy - nie są przez to uznawane za wytwór specyficznych stosunków społecznych, ale postrzegane jako rezultat postępu technologicznego (mniej lub bardziej nieuchronnego, przynajmniej w Europie?).

Ja sugeruję natomiast, że dynamika kapitalistyczna zakorzeniona w nowej formie społecznych stosunków własności chronologicznie i przyczynowo poprzedzała industrializację. W istocie pewien rodzaj „społeczeństwa rynkowego”, a zatem takiego, w którym wytwórcy byli uzależnieni od rynku - w sensie rynkowego dostępu do środków utrzymania, pracy i własnej reprodukcji - i podporządkowani jego imperatywom, był nie tyle rezultatem industrializacji, co jego podstawową przyczyną. Tylko transformacja w obrębie społecznych stosunków własności, która wymusiła na ludziach, żeby produkowali konkurencyjnie (a nie jedynie kupowali tanio, by sprzedawać drożej) i uzależniła dostęp do środków produkcji od rynku, może wytłumaczyć dramatyczne rewolucjonizowanie sił wytwórczych, które okazało się specyficzne dla nowoczesnego kapitalizmu.

Wynika z tego, że narodziny kapitalizmu nie moga być wyjaśnione jako rezultat ulepszeń technicznych, efekt „obecnej w Europie Zachodniej tendencji postępu gospodarczego” lub też $\mathrm{w}$ odniesieniu do jakiegokolwiek innego ponadhistorycznego mechanizmu. A specyficzna transformacja społecznych stosunków własności, która zainicjowała historycznie unikalny „rozwój” sił wytwórczych, nie może być traktowana jako dana i trzeba ją wyjaśnić.

\section{IV}

Problemem nie jest tutaj tylko różnica zdań co do konkretnego procesu historycznego, w wyniku którego powstał kapitalizm, ale to, że sposób, w jaki rozumiemy jego historię, ma wiele wspólnego z tym, jak go pojmujemy. Stare modelu rozwoju kapitalistycznego były paradoksalną mieszanką ponadhistorycznego determinizmu i „wolnorynkowego" woluntaryzmu, w której rynek kapitalistyczny uchodził zarazem za niezmienne prawo naturalne oraz szczyt doskonałości ludzkiego wyboru i wolności. Antytezą dla wspomnianych ujęć byłaby 
taka koncepcja rynku kapitalistycznego, która w pełni dostrzega jego imperatywy i przymusy, uznając je za zakorzenione nie w jakimś ponadhistorycznym prawie naturalnym, ale w historycznie specyficznych stosunkach społecznych. Te zaś traktowane są na jej gruncie jako konstytuowane są przez działalność człowieka i jako takie mogą zostać zmienione. Można by oczekiwać, że taka koncepcję rozwija marksizm. Jakie jest zatem jego miejsce w tych historycznych debatach? Co marksistowscy historycy mieli do powiedzenia na temat historii rynku? Okazuje się, że różnice zdań pomiędzy marksistami są tak duże jak pomiędzy historykami burżuazyjnymi. Wielu marksistów (nie wyłączając samego Marksa w jego wczesnych pismach ${ }^{3}$ ) było tak samo przywiązanych do starego modelu handlowego jak pozostali badacze, a ich zaufanie do determinizmu technologicznego było nawet większe. Inni byli wobec niego bardzo krytyczni, choć nawet u nich widać było silny wpływ tego modelu. Dyskusja na ten temat nadal się toczy i wciąż pozostaje na jej gruncie wiele do zrobienia.

Najważniejszą debata, która toczyła się w tej kwestii między marksistami, jest tzw. „debata na temat przejścia” [od feudalizmu do kapitalizmu]. Zainicjowała ją wymiana między Paulem Sweezym i Mauricem Dobbem w Science and Society we wczesnych latach pięćdziesiatych dwudziestego wieku4 . Do głównych tematów debaty należała rola miast i handlu w przejściu [z feudalizmu do kapitalizmu], a szczególnie kwestia tego, czy handel, zwłaszcza wzrost dalekosiężnego handlu między Wschodem a Zachodem (w sensie przyjmowanym przez Pirenne’a), spowodował upadek feudalizmu. Innymi słowy, czy główny czynnik upadku był zewnętrzny wobec podstawowych stosunków feudalnych, czy też przyczyn ich dekompozycji i powstania kapitalizmu trzeba szukać w obrębie tych stosunków (tj. między panami i chłopami).

Sweezy twierdził, że feudalizm (ze wszystkimi swoimi brakami i nierównowagami) był w swojej istocie trwały i odporny na zmianę, a główna siła napędowa jego upadku musiała pochodzić z zewnątrz. System ten mógł tolerować, a nawet potrzebować pewnej ilości handlu, ale wraz z ustanowieniem lokalnego handlu miejskiego i ośrodków przeładunkowych opartych na handlu dalekosiężnym (Sweezy odwołuje się tu do Pirenne’a) został uruchomiony proces sprzyjający produkcji przeznaczonej na wymianę. To z kolei rodziło napięcie $z$ feudalną zasada produkcji użytkowej. „Z reguły myślimy o przejściu z jednego systemu społecznego do innego jako o procesie, w którym te dwa systemy konfrontują się bezpośrednio i rywalizuja o dominację”, ale „myślenie w ten sposób o przejściu z feudalizmu do kapitalizmu” byłoby poważnym błędem (Hilton 1976, 49).

\footnotetext{
${ }^{3}$ Więcej na temat ewolucji poglądów Marksa w kwestii historii, rozwoju kapitalizmu, podziału pracy i rewolucji burżuazyjnej, zob. Comninel 1987; Brenner 1989.

${ }^{4}$ Całą debatę, w której wzięli udział także inni znaczący marksistowscy historycy, opublikowano później z kilkoma dodatkowymi tekstami w: Hilton 1976.
} 
Sweezy nie starał się wyjaśnić drugiej fazy tego procesu, ale podniósł istotne kwestie w związku z wyjaśnieniami, które zaproponowali inni. Dwie są tu szczególnie ważne. Po pierwsze, Sweezy był sceptyczny wobec poglądu (wynikającego z konwencjonalnej interpretacji Marksowskiej „rzeczywiście rewolucyjnej drogi” wiodącej do przemysłowego kapitalizmu), zgodnie z którym kapitaliści przemysłowi wywodzili się z szeregów drobnych wytwórców. Sam proponował ujęcie tej „drogi” jako procesu, w którym wytwórca nie tyle przechodzi od pozycji drobnego producenta przez kupca do kapitalisty, co ,jest od początku zarówno kupcem, jak i pracodawcą (w systemie pracy najemnej) [employer of wage-labor]”. W ten sposób kapitalistyczne przedsięwzięcia maja już na starcie pełnoprawny charakter, a nie rozwijają się stopniowo, wychodząc od drobnej działalności w systemie nakładczym (Hilton 1976, 54). Druga kwestia dotyczyła tego, że nawet pełne upowszechnienie się produkcji towarowej nie mogło odpowiadać za narodziny kapitalizmu, co potwierdzały przypadki wysoce rozwiniętych w tej kwestii średniowiecznych Włoch i Flandrii (Hilton 1976, 106-107).

Oponenci Sweezy’ego, zwłaszcza Maurice Dobb i Rodney Hilton, twierdzili natomiast, że handel jako taki nie doprowadził do upadku feudalizmu (szczególnie ten drugi podkreślał empiryczną błędność argumentu Pirenne’a). Kładli oni nacisk na to, że główny czynnik przejścia, którego poszukiwał Sweezy, można znaleźć w relacjach między panami a chłopstwem. Hilton pokazał, w jaki sposób pieniądz, handel, miasta, a nawet tak zwana „rewolucja handlowa” były integralne dla systemu feudalnego. Oznaczało to, że choć przyczyniły się one do transformacji, to nie można uznać ich za sprzeczne albo wrogie feudalizmowi, a zatem nie mogą być kluczem do jego upadku.

Zarówno Dobb i Hilton sugerowali na różne sposoby, że upadek feudalizmu i powstanie kapitalizmu było wynikiem wyzwolenia drobnej produkcji towarowej spod okowów feudalizmu, co działo się z pomocą walki klasowej między panami a chłopami. Dobb twierdził przykładowo, że podczas gdy walka klasowa w żaden „prosty i bezpośredni sposób” nie przyczyniła się do powstania feudalizmu, to odegrała swoją rolę:

\begin{abstract}
w zmniejszeniu zależności prostej (drobnej) produkcji towarowej od feudalnego panowania i ostatecznym wyzwoleniu drobnego wytwórcy z feudalnego wyzysku. Kapitalizm wyłania się zatem z prostej produkcji towarowej (w stopniu, w jakim zabezpiecza niezależność działania, pozwalając na powstanie w swoich ramach społecznego zróżnicowania) (Hilton 1976, 59).
\end{abstract}

Hilton sugerował w podobny sposób, że nacisk wywierany przez panów na chłopów był główną przyczyną doskonalenia technik produkcji i podstawą wzrostu prostej produkcji towarowej. Z kolei opór chłopów wobec tego nacisku był niezmiernie istotny w procesie przejścia do kapitalizmu - „uwolnienie gospodarek chłopskich i rzemieślniczych spowodowało 
rozwój produkcji towarowej i ostatecznie powstanie kapitalistycznego przedsiębiorcy" (Hilton 1976, 27).

Podsumowanie to jest oczywiście dużym uproszczeniem i streszczeniem złożonych argumentów wysuwanych przez uczestników debaty, niemniej powinno być wystarczające do zadania kilku krytycznych pytań na temat założeń, na których opierały się obie strony. $\mathrm{Na}$ pierwszy rzut oka to Sweezy wydaje się być najbardziej przywiązany do modelu handlowego, a jego oponenci zdają się od niego odbiegać. Kwestia ta nie jest jednak taka prosta. Po bliższym zbadaniu sprawy nie jest wcale takie jasne, czy Dobb i Hilton kwestionuja wszystkie podstawowe założenia modelu handlowego. Pytania stawiane przez Sweezy'ego dotykaja z kolei samego sedna nierozwiązanych przez nich problemów. W argumentach Dobba i Hiltona wyróżnia się jedna rzecz: przejście do kapitalizmu jest kwestią emancypacji, wyzwolenia logiki ekonomicznej już obecnej w prostej produkcji towarowej. Pozostajemy zatem z przytłaczającym wrażeniem, że jeżeli wytwarzający towary chłop (albo rzemieślnik) dostanie taką szansę, przeistoczy się w kapitalistę. Środek ciężkości tego argumentu mógł się przesunąć z miasta na wieś, a walce klasowej dano nowe znaczenie, ale jak bardzo różnią się leżące u podstaw tego argumentu założenia od głównych przesłanek modelu handlowego? Jak daleko jesteśmy od przesłanki, zgodnie z którą kapitalistyczny rynek jest raczej możliwościa aniżeli imperatywem, a to, co wymaga konceptualizacji w zobrazowaniu powstania kapitalizmu, to przełamanie barier, usunięcie ograniczeń, a nie powstanie całkowicie nowej logiki ekonomicznej?

Problemy, które martwily Sweezy'ego w jego polemice z Dobbem są tutaj niezwykle aktualne. Po pierwsze, nawyk traktowania przejść jako konfrontacji między dwoma antytetycznymi sposobami produkcji jest nazbyt często wymówką dla błędu niedostatecznego wyjaśnienia (petitio principii). Jak sugerował to Sweezy, choć kwestia ta może mieć inne znaczenie w przejściu od kapitalizmu do socjalizmu, to nawyk ten jest szczególnie problematyczny w przejściu od feudalizmu do kapitalizmu. Jak widzieliśmy, model handlowy $\mathrm{i}$ inne powiązane koncepcje $\mathrm{w}$ zasadzie zakładaja istnienie kapitalizmu albo kapitalistycznej racjonalności w celu wyjaśnienia jej powstania. Feudalizm staje w obliczu „już istniejącego” kapitalizmu (przynajmniej w formie embrionalnej), którego powstanie nie zostaje nigdy wyjaśnione. Uzasadnienia proponowane przez marksistów takich jak Hilton i Dobb, choć w wielu miejscach druzgocące dla modelu handlowego i jego założeń o przeciwieństwie feudalizmu i handlu, nie uniknęły w całości tej pułapki, zakładając istnienie tego, co samo powinno zostać wyjaśnione.

Badacze ci nie daja też w pełni przekonującej odpowiedzi na pytania zadane przez Sweezy'ego o to, dlaczego rozwinięte ośrodki handlowe (takie jak te we Włoszech i Flandrii) odniosły porażkę. Ponownie widać tu tendencję do brania kapitalizmu za pewnik poprzez uproszczone wyjaśnienie præeszłkód, które nie pozwoliły uzyskać dojrzałości włoskim 
i flandryjskim miastom handlowym. W pytaniu dotyczącym Flandrii i Włoch nie chodzi do końca o to, dlaczego i w jakich okolicznościach kapitalistyczne imperatywy zdominowały ekonomiczne podmioty, tak jak miało to miejsce w Anglii. Chodzi raczej o to, dlaczego i w jaki sposób ekonomiczni uczestnicy ,nieudanych” transformacji byli niechętni albo niezdolni - nie tylko z powodów ideologicznych i kulturowych - do zerwania ze swoim przywiązaniem do feudalizmu w celu stworzenia nowej formy społecznej (Hilton 1976, 157-159).

Istnieją też solidne podstawy dla sceptycyzmu Sweezy'ego wobec „rzeczywiście rewolucyjnej drogi”. Idea ta pojawia się w szczególności u Dobba (choć nie tylko) i polega na wywodzeniu kapitalistycznych rolników od drobnych właścicieli ziemskich. Ponownie problemem jest tutaj to, że yeomeni ${ }^{5}$, gdy już wyzwolą się z feudalnych okowów, często są przedstawiani jako mniej lub bardziej wolni w obieraniu drogi wiodącej ku kapitalizmowi. Ten zaś traktowany jest jako mniej lub bardziej organiczny rezultat postępu, którego początek wyznacza prosta produkcja towarowa (nawet jeśli potrzebuje do tego rewolucji burżuazyjnych, które usuwają ostatnie przeszkody na jego drodze). Wyzwolenie od ograniczeń albo ewolucja od „drobnicy” do wielkich posiadaczy to jednak nie wszystko - musi istnieć jakieś inne wytłumaczenie dla skłonności, zgodnie z którą wytwórcy zaczynają działać jak kapitaliści. Niewyjaśniona pozostaje również jakościowa różnica między prostą produkcją towarową a kapitalizmem.

\section{V}

To, czego nie wyjaśniła „debata na temat przejścia” i o co w gruncie rzeczy nigdy nie zapytano, to kwestia, jak i w jakich okolicznościach wytwórcy zostali podporządkowani imperatywom rynkowym. Marksiści kontynuowali jednak samą dyskusję w odniesieniu do innych problemów. Istotny wkład wniósł do niej historyk Robert Brenner, który starał się wyjaśnić przejście z feudalizmu do kapitalizmu, zarówno bez wywodzenia kapitalistycznych reguł ze społeczeństw przedkapitalistycznych, jak i nie zakładając z góry tego, co chciał wyjaśnić. Odrzucał w tym celu model przejścia z feudalizmu do kapitalizmu, w którym konfrontują się ze sobą dwa antagonistyczne sposoby produkcji. Nie było embrionalnego kapitalizmu ukrytego w szczelinach feudalizmu - ani w przedkapitalistycznych formach handlu, ani w prostej produkcji towarowej jako wersji „protokapitalizmu”. Brenner krytykował inne koncepcje przejścia za zlekceważenie „wewnętrznej logiki i spójności” przedkapitalistycznych gospodarek i założenie, że aktorzy ekonomiczni, jeżeli da im się taką szansę, musza przyjąć strategie kapitalistyczne. Krytyka ta, choć nie pisał o tym wprost, pasuje zarówno do modelu handlowego, jak i teorii ewolucji prostej produkcji towarowej. Spostrzeżenie to miało dla

\footnotetext{
${ }^{5}$ Chłopi posiadający własność ziemską (przyp. tłum.).
} 
Brennera dalsze konsekwencje. Nie starał się on odnaleźć zewnętrznego czynnika, który doprowadził do upadku kapitalizmu (w kontekście pewnych stosunków własności to handel prowadził raczej do wzmocnienia aniżeli osłabienia przedkapitalistycznych form własności), ale dostrzec wewnętrzną logikę feudalizmu, która nie presuponuje kapitalizmu. Walka klasowa odgrywa w jego argumentacji ważną rolę, podobnie zreszta jak w koncepcjach Dobba i Hiltona, nie jest tu ona jednak tożsama z kwestią wyžmolenia impulsu do powstania kapitalizmu. Wiąże się raczej z panami i chłopami, którzy w specyficznych warunkach charakterystycznych dla Anglii nieświadomie uruchomili kapitalistyczną dynamikę, próbując przy tym odtwarzać swój byt takim, jaki on byt. Doprowadzili w ten sposób do sytuacji, w której wytwórcy zostali podporządkowani imperatywom rynkowym - nie moغ̇liwości produkcji dla rynku i rozwoju od drobnych wytwórców aż do kapitalistów, ale potrzebie specjalizacji w ramach rynku i konkurencyjnej produkcji, a to w celu zagwarantowania sobie dostępu do środków utrzymania.

Nie ma tutaj miejsce na wchodzenie w szczegóły ${ }^{6}$. Wystarczy nam to, że wyjaśnienie Brennera uwzględnia bardzo specyficzne uwarunkowania angielskich stosunków własności, gdzie wyjątkowa duża część ziemi należała do właścicieli ziemskich zatrudniających do jej uprawy dzierżawców. Z czasem warunki dzierżawy zaczęły przybierać formę kapitalistycznego najmu, co w rezultacie zmuszało dzierżawców do rywalizacji na konkurencyjnych zasadach zarówno na rynku konsumenckim, jak i w odniesieniu do ziemi, a to z kolei prowadziło do konkurencyjnej produkcji, aby mogli oni opłacić czynsze. Jednocześnie nastapiła demilitaryzacja angielskich właścicieli ziemskich (wcześniej niż innych europejskich arystokracji), a państwo angielskie zostało w sposób wyjątkowy scentralizowane - bez rozpraszania władzy suwerennej, co było charakterystyczne dla państw feudalnych. Oznaczało to, że choć państwo służyło teraz arystokracji jako instrument zaprowadzania porządku, to klasa panująca była w nietypowy sposób pozbawiona autonomicznych, „pozaekonomicznych” możliwości albo tego, co Brenner określa mianem „,politycznie konstytuowanej własności”. Mowa tu o niezależnych politycznych, sądowych i militarnych uprawnieniach, dzięki którym klasy wyzyskujące w społeczeństwach przedkapitalistycznych - np. panowie feudalni przywłaszczały sobie prace dodatkowa. Ta specyficzna klasa ziemska stawała się z czasem coraz bardziej zależna nie tyle od wywierania przymusu na dzierżawcach i „wyciskaniu” z nich jak większej nadwyżki, ale od ich produktywności. W momencie ugruntowania się konkurencyjnych, „sił rynkowych” mniej wydajni chłopi znaleźli się pod ściana, co w połączeniu $\mathrm{z}$ ich siłowym wywłaszczeniem albo pozbawianiem praw zwyczajowych przyspieszyło polaryzację angielskiego społeczeństwa wiejskiego na dużych właścicieli ziemskich i coraz większą, pozbawioną własności masę. Rezultatem tego była słynna „triada”

\footnotetext{
${ }^{6}$ Najistotniejsze wypowiedzi Brennera na temat przejścia można znaleźć w: Brenner 1985.
} 
właściciela ziemskiego, kapitalistycznego dzierżawcy i pracownika najemnego. Wraz z upowszechnianiem się pracy najemnej zwiększał się też nacisk na ulepszanie produktywności pracy. Ten sam proces spowodował powstanie niezwykle wydajnego rolnictwa zdolnego do utrzymania dużej populacji niezaangażowanej w produkcję rolną, ale też coraz większej, pozbawionej własności masy, która stała się podwaliną dla zarówno potężnej siły roboczej, jak i bezprecedensowego w historii taniego, krajowego rynku dóbr konsumenckich. W tym właśnie kontekście formował się angielski kapitalizm przemysłowy.

Chociaż Brenner był oczywiście zainspirowany koncepcjami Dobba i Hiltona, to różnica w ich argumentacji powinna być teraz wyraźna. Istota jego wyjaśnienia jest przymus albo imperatyw, a nie możliwość. Jeżeli swą rolę odgrywa tu, dla przykładu, drobny właściciel ziemski, to dzieje się to w kontekście podporządkowania imperatywowi, a nie danych mu możliwości. Z reguły to dzierżawcy byli właśnie tym typem kapitalistycznych najemców, którzy podlegali presji konkurencyjności angielskiej triady. Gdy konkurencyjna produktywność agrarnego kapitalizmu zaczęła wyznaczać warunki ekonomicznego utrzymania, zaczęli jej nawet podlegać wielcy posiadacze ziemscy. Zarówno właściciele ziemscy, jak i dzierżawcy stali się teraz zależni od sukcesu na rynku - renta tych pierwszych związana była bowiem z zyskami osiaganymi przez drugich. Mieli oni zatem interes w rolniczym „ulepszaniu” - poprawie produktywności poprzez odkrywcze wykorzystanie ziemi i technik produkcji rolnej, co często skutkowało między innymi grodzeniem ziemi (nie wspominając o wyzysku siły roboczej).

Kolejny z uczestników „debaty na temat przejścia” w swoim komentarzu nieświadomie ilustruje różnicę między modelem „rynku możliwości” a „rynku jako imperatywu” (choć w sposób, którego taki specjalista jak Hilton raczej by unikał). John Merrington, bo o nim tu mowa, w swoim ważnym artykule o strukturalnej roli miast w feudalizmie sugerował, że chociaż przemiana feudalnej pracy dodatkowej w formę renty pieniężnej sama w sobie nie zmieniła natury stosunków feudalnych, gdyż jej wysokość określała ilość pracy dodatkowej na względnie stałym poziomie, to jednak umożliwiła „stymulację rozwoju samodzielnej produkcji towarowej" (Hilton 1976, 179). To twierdzenie jest w mniejszym stopniu poparte empirycznymi dowodami, a bardziej na założeniu o tym, że drobni wytwórcy, gdy dostaną taką szansę, zawsze będą działać na modłę kapitalistyczna. W przeciwieństwie do tego Brenner pokazywał, jak niezwiazane $i$ arbitralnie określane renty, które funkcjonowały jako renty ekonomiczne zgodnie z rynkowymi imperatywami, stymulowały rozwój produkcji towarowej, ulepszania produktywności i ciagłego wzrostu gospodarczego. Gdzie indziej, na przykład we Francji, gdzie chłopi z reguły byli dzierżawcami ziemi, płacąc stałe i nominalne renty, takiego bodźca zabrakło.

W pewnym sensie Brenner odpowiedział również na pytanie Sweezy'ego dotyczące „rzeczywiście rewolucyjnej drogi”. Kapitalistyczny dzierżawca w Anglii nie był po prostu drobnym wytwórca, który wyrósł na kapitalistę. Jego specyficzny stosunek do środków 
produkcji i warunki, w których miał dostęp do ziemi, czyniły z niego kapitalistę na samym starcie. Stawał się przez to podporządkowanym imperatywom rynkowym wytwórcą. Sam też zatrudniał zwykle pracowników najemnych.

Pouczające będzie tu zestawienie tej sytuacji z przeciwstawnym jej przypadkiem francuskim. We Francji arystokracja długo utrzymywała w swoich rękach politycznie konstytuowaną własność i „pozaekonomiczne” możliwości wyzysku. Kiedy feudalizm został tam wyparty przez absolutyzm, środki te nie zostały zastapione przez czysto ekonomiczny wyzysk albo produkcję kapitalistyczną. Zamiast tego francuska klasa panująca uzyskała nowe uprawnienia pozaekonomiczne, ponieważ w ramach państwa absolutnego powstał potężny aparat urzędniczy, poprzez który część klasy posiadającej mogła przywłaszczać sobie nadwyżkę pracy chłopów w formie podatków. I nawet wówczas, u szczytu absolutyzmu, Francja była zagmatwanym kotłem wojujących ze sobą jurysdykcji - szlachta i władze miejskie trzymały się resztek autonomicznych władz feudalnych, pozostałości po feudalnej „rozdrobnionej suwerenności”. W tych warunkach preferowaną ekonomiczna strategia było wciąż raczej wywieranie nacisku na chłopów środkami pozaekonomicznymi aniżeli zachęcanie ich do konkurencyjnej produkcji i „ulepszania”. Nie istniał tam pęd do kapitalistycznego rozwoju, który byłby porównywalny z Anglią, dopóki jej samej nie udało się narzucić presji konkurencji na gospodarkę międzynarodowa. Miał to być wzorzec rozwoju również dla innych społeczeństw kapitalistycznych - kiedy to zewnętrzna presja konkurencyjności w systemie międzynarodowym zmusi inne państwa do wspierania własnego rozwoju gospodarczego.

Warto też zauważyć, że jednolity rynek krajowy, który Polanyi określił jako pierwszy konkurencyjny rynek, rozwinął się w Anglii na długo przed jakimkolwiek innym państwem. Francja musiała czekać aż do epoki napoleońskiej, ażeby usunąć wewnętrzne bariery handlowe. Istotne jest to, że rozwój konkurencyjnego rynku krajowego był następstwem - a nie przyczyną - kapitalizmu i „społeczeństwa rynkowego”. Ewolucja jednolitego i konkurencyjnego rynku krajowego odzwierciadlała przekształcenia w naturze sposobu wyzysku i istoty państwa. $\mathrm{Na}$ przykład we Francji utrzymywanie się „pozaekonomicznych” metod wyzysku - nie tylko $\mathrm{w}$ formie państwa-urzędu, ale też w formie pozostałości starych arystokratycznych jurysdykcji albo władz korporacji zawodowych i odziedziczonych po feudalizmie przywilejów - oznaczało, że ani państwo, ani gospodarka nie były w pełni zintegrowane. To „korporacyjne” rozdrobnienie społeczeństwa było taką samą częścią absolutyzmu, jak scentralizowana biurokracja, do której odnoszą się przede wszystkim konwencjonalne stereotypy na temat państwa absolutnego. W Anglii, gdzie istniał wyraźny rozdział między polityczna, siłowa władza państwa a eksploatacyjnymi możliwościami klas panujących, które swoje bogactwa zawdzięczały czysto „ekonomicznym” formom wyzysku, prywatne uprawnienia ekonomiczne klas panujących nie umniejszały politycznej jedności państwa. Współistniało więc prawdziwie scentralizowane państwo i jednolity rynek krajowy. 
Argument Brennera - poprzez wykazanie, jak bezpośredni wytwórcy zostali podporządkowani imperatywom rynkowym - wyjaśnia zatem kontekst, w którym zmieniła się sama natura handlu i rynków dzięki uzyskaniu zupełnie nowej roli ekonomicznej i nowej systemowej logiki. Stało się to na długo przed industrializacją i było jej warunkiem wstępnym. Innymi słowy, imperatywy rynkowe zostały narzucone bezpośrednim wytwórcom, zanim nastąpiła masowa proletaryzacja siły roboczej. Imperatywy rynkowe były (jako „siły rynkowe”) decydującym czynnikiem w stworzeniu masowego proletariatu przy wsparciu bezpośredniego nacisku w formie interwencji politycznej i sądowniczej, tworząc w ten sposób pozbawioną własności większość.

Jednak proletaryzacja, która oznaczała całkowite utowarowienie siły roboczej, przyznała rynkowi nowe i dalej sięgające przymusowe uprawnienia, co było możliwe dzięki stworzeniu całkowicie od niego zależnej i pozbawionej innego dostępu do zasobów klasy robotniczej. Nie wystarczy też powiedzieć, że zarówno kapitał, jak i praca były podporządkowane na rozmaite sposoby bezosobowej władzy rynku. Sam rynek stał się główną osia podziału klasowego między wyzyskiwaczami i wyzyskiwanymi, między kupującymi i sprzedającymi siłę roboczą. Stał się nowym, zniewalającym narzędziem w rękach kapitału, ostateczną dyscypliną służącą jego kontroli nad praca.

Sposób, w jaki ugruntowało się „społeczeństwo rynkowe” w tym okresie, najlepiej przedstawił w swoich pracach E.P. Thompson. Jego powstanie jest tam opisane nie tylko jako proces proletaryzacji (tak w jego klasycznym dziele The Making of the English Working Class, jak również tekstach na temat osiemnastego wieku), ale jako żywa konfrontacja między „społeczeństwem rynkowym” a alternatywnymi wartościami i praktykami. Urzeczywistnianie takiego społeczeństwa jawi się też jako konfrontacja między klasami. Pomiędzy tymi, których interesy wyrażała nowa ekonomia polityczna rynku (wraz ze swoją filozofią „polepszania”), a tymi, którzy się im przeciwstawiali, przedkładając prawo do przeżycia nad imperatywy zysku.

Dla tych, którzy się zastanawiaja, dlaczego Thompson po napisaniu The Making of the English Working Class wrócił do badań nad osiemnastym wiekiem, a nie kontynuował swoich badań, wychodząc poza lata trzydzieste dziewiętnastego wieku, żeby w pełniejszy sposób ująć proces industrializacji, odpowiedź może być następująca: starał się wytłumaczyć powstanie kapitalizmu jako formy społecznej, a nie neutralnych przekształceń technologicznych zwanych „industrializacją”. Interesował się osiemnastym wiekiem przede wszystkim jako momentem, w którym kapitalistyczne przekształcenie stosunków własności zostało skonsolidowane i zaczęło wyrażać nową kapitalistyczną ideologię w sposób bardziej świadomy i bezpośredni niż kiedykolwiek wcześniej. Był to też moment, w którym sprzeciw wobec nowych reguł ekonomicznych nie został jeszcze podporządkowany hegemonicznej ideologii - czyli ekonomii 
politycznej rynku - która niedługo później zinfiltrowała nawet najbardziej radykalne przejawy opozycji względem kapitalizmu.

Thompson sugerował, że w osiemnastowiecznej Anglii rynek był w istocie główną areną walki. Było to bardzo charakterystyczne właśnie dla tego „przejściowego” momentu w angielskiej historii. Z jednej strony był to okres „wolnej” pracy, która nie była już podporządkowana przedkapitalistycznym, pozaekonomicznym formom dominacji. Nie dochodziło przy tym jeszcze do jej uwikłania w nowe dyscypliny fabryczne, dzięki czemu przez krótki czas ludzie kontrolowali „swoje bezpośrednie stosunki i sposoby pracy” (Thompson 1991, 74). Z drugiej strony „mieli już bardzo małą kontrolę nad rynkiem, gdy idzie o ich produkty lub ceny surowców i jedzenia”. Z tego powodu protesty społeczne były tak często wymierzone w rynek. Ludzie (zazwyczaj kobiety) sprzeciwiali się nie tylko niesprawiedliwym płacom, ale też nieuprawnionym i niemoralnym praktykom rynkowym, których celem był zysk. Z perspektywy „społeczeństwa rynkowego” i kapitalistycznej racjonalności wydaje się to być dzisiaj zupełnie normalne, ale wówczas uderzało w pewne zwyczajowe oczekiwania związane z dostępem do środków utrzymania.

W niektórych z tych protestów widać opozycję wobec przekształcania się rynku z widzialnej i mniej lub bardziej transparentnej instytucji w „niewidzialną rękę”. Najbliższa ludziom postać rynku przybierała wówczas formę fizycznego miejsca, gdzie oferowano towary na sprzedaż w zgodzie z zasadami regulowanymi wciąż w dużej mierze przez zwyczaj, prawa miejskie, oczekiwania dotyczące prawa do utrzymania i przez to, co Thompson określił słynnym mianem „ekonomii moralnej ludu”. Kiedy rynek zaczął się przekształcać w mechanizm będący poza wspólnotową kontrolą, transparentność jego transakcji została wyparta przez tajemnice „samoregulacji”, mechanizm cenowy i podporządkowanie wspólnotowych wartości imperatywom zysku.

Thompson pokazywał też, jak nowa ideologia ekonomii politycznej wraz z nowymi koncepcjami własności, etyką zysku i stojącym u ich podstaw „ulepszaniem”, były w coraz większym stopniu siłowo wprowadzane przez państwowe represje. Racje stojące za „ulepszaniem”, czyli prawa właściciela do zysku pochodzącego z rosnącej produktywności, były stawiane przez sądy ponad prawami zwyczajowymi albo prawem do utrzymania. Władza świecka brutalnie reagowała (zwłaszcza po Rewolucji Francuskiej) na protesty przeciwko nieuczciwym cenom i praktykom rynkowym. Innymi słowy, przymus państwa był konieczny do narzucenia przymusu rynku.

\section{VII}

Wiele kwestii dotyczących roli rynków, miast i handlu w historii kapitalizmu wciąż pozostaje otwartych. Ale nawet samo uznanie, że kapitalizm nie wywodzi się z ponadhistorycznych form 
handlu, ani też nie jest wynikiem rozwoju technologicznego; oraz dostrzeżenie konsekwencji stosunków społecznych, które kształtują rynek kapitalistyczny, ma istotne implikacje.

Jestem przykładowo przekonana, że rozmaite programy polityczne lewicy - od postulatów socjaldemokratycznych w rodzaju społecznej gospodarki rynkowej w ramach kapitalizmu do bardziej radykalnych teorii „socjalizmu rynkowego” - sa wciąż oparte na iluzjach co do natury rynku jako sfery możliwości i wyboru. Nie są też w stanie dostrzec wszystkich konsekwencji traktowania rynku jako regulatora ekonomicznego. Wciąż pamiętam - choć uderzające do głowy dni komunistycznego upadku wydają się już bardzo odległe - jak idealistyczni demokraci z Europy Wschodniej odpowiadali na ostrzeżenia zachodniej lewicy na temat rynku (gdy wydawało się, że na Zachodzie wciąż istnieje jeszcze antyrynkowa lewica, która może wejść w dialog z postępowymi siłami w ramach byłych państw komunistycznych). Gdy ostrzegano ich, że „rynek” oznacza nie tylko supermarkety z dużą ofertą, ale też masowe bezrobocie i biedę, odpowiedź brzmiała: „Tak, ale nie to mamy na myśli, gdy mówimy o rynku”. Cała idea polegała na tym, że można sobie wybrać dowolne elementy z samoregulującego się rynku. Rynek może regulować gospodarkę w takim stopniu, żeby zagwarantować jej pewną „racjonalnośc”, korespondencję między tym, czego ludzie chcą a tym, co jest wytwarzane. Rynek może być jak sygnał, źródło informacji, sposób komunikacji między konsumentami i producentami; może też być gwarantem tego, że słabe albo nieefektywne przedsiębiorstwa poprawią się lub zbankrutują. Poradzimy sobie jednak z jego ciemną strona.

Wszystko to może się teraz wydawać ludziom z Europy Wschodniej naiwne, co upodobniałoby ich stanowisko do tego, które prezentowali niegdyś zachodni marksiści. Nie jest jednak wcale takie jasne, czy dzisiaj wielu lewicowców na Zachodzie jest choć trochę mniej skłonnych do myślenia, że rynek jako ekonomiczny regulator można podporządkować wyborowi między jego dobroczynnym wpływem a bardziej niszczącymi konsekwencjami. Trudno jest wytłumaczyć w inny sposób pojęcie „socjalizmu rynkowego” albo nawet mniej utopijną koncepcję „społecznej gospodarki rynkowej”, gdzie ekscesy rynkowe maja być kontrolowane przez regulacje państwową i wzmocnienie praw socjalnych.

Nie chce przez to powiedzieć, że „społeczna gospodarka rynkowa” nie jest lepsza niż kapitalizm wolnorynkowy. Nie mam też zamiaru sugerować, że pewne instytucje i praktyki, które towarzyszą rynkowi, nie moga zostać zaadaptowane do gospodarki socjalistycznej. Nie należy jednak wzbraniać się przed implikacjami jednego niezbywalnego warunku, bez którego rynek nie mógłby działać jako dyscyplina ekonomiczna: utowarowienia siły roboczej. Warunku, który kładzie najbardziej rygorystyczne ograniczenie na „uspołecznienie” rynku i jego możliwości przybrania „ludzkiej twarzy”7.

\footnotetext{
${ }^{7}$ Dyskusję na ten temat można znaleźć w: McNally 1993.
} 
Rynek wciąż dziś działa nie tylko jako „bezosobowy” imperatyw, ale też jako bezpośredni instrument władzy klasowej wykorzystywany przez kapitał do kontrolowania pracy (nie wspominając o jego roli jako medium nowego imperializmu, w którym zaawansowane gospodarki kapitalistyczne nakładają z pomocą państwa rynkową „dyscyplinę” na Trzeci Świat i „nowe demokracje”). Aby uniknąć ekscesów społeczeństwa rynkowego, potrzeba będzie większych transformacji, niż przewidział to Polanyi. Ale też wbrew jego wyobrażeniom kapitalizm - jako historycznie specyficzna forma społeczna - może okazać się dużo bardziej otwarty na opór i kolejną, ,wielką transformację”.

W momencie jego „długiego upadku” sami kapitaliści - w swoich coraz bardziej desperackich żądaniach elastyczności - wydają się blisko przyznania, że imperatywy kapitalistycznego rynku nie pozwolą im na rozwój bez pogorszenia warunków robotników i degradacji środowiska. W takich okolicznościach socjalizm może się okazać mniej nierealistyczny i utopijny niż ,społeczny” kapitalizm. 


\section{Wykaz literatury}

Brenner, Robert. 1985. „Agrarian Class Structure and Economic Development in PreIndustrial Europe". W The Brenner Debate: Agrarian Class Structure and Economic Development in Pre-Industrial Europe, red. T.H. Aston i C.H.E. Philpin. Cambridge: Cambridge University Press.

Brenner, Robert. 1989. „Bourgeois Revolution and Transition to Capitalism”. W The First Modern Society, red. A.L. Beier i David Cannadine. Cambridge: Past and Present Publications.

Comninel George. 1987. Rethinking the French Revolution: Marxism and the Revisionist Challenge. London: Verso.

Fusfeld, Daniel. 1993. „The Market in History”. Monthly Review 45.

Hilton, Rodney (red.). 1976. The Transition from Feudalism to Capitalism. London: New Left Books.

Kerridge, Eric. 1988. Trade and Banking in Early Modern England. Manchester: Manchester University Press.

McNally, David. 1994. Against the Market. London: Verso.

Meiksins Wood, Ellen. 1995. Democracy Against Capitalism: Renewing Historical Materialism. Cambridge: Cambridge University Press.

Pirenne, Henri. 1952. Medieval Cities: Their Origins and the Revival of Trade. Princeton: Princeton University Press.

Polanyi Karl. 2010. Wielka transformacja: politycz̨e i ekonomicz̨ne źródła naszych czasów. Tłum. Maria Zawadzka. Warszawa: Wydawnictwo Naukowe PWN.

Thompson, E.P. 1991. Customs in Common. London: Penguin Books. 
Ellen Meiksins Wood (1942-2016) - była amerykańską historyczką marksistowską i teoretyczka. Wraz z Robertem Brennerem stworzyła nurt nazywany „marksizmem politycznym”. Autorka wielu książek, między innymi The Retreat from Class (1986), za która otrzymała nagrodę im. Isaaca Deutschera, oraz wpływowej pracy The Origin of Capitalism (1999).

CYTOWANIE: Meiksins Wood, Ellen. 2017. „Od możliwości do imperatywu: historia rynku." Praktyka Teoretyczna 4 (26): 320-342.

DOI: $10.14746 /$ prt.2017.4.12

AUTHOR: Ellen Meiksins Wood

TITLE: From Opportunity to Imperative: The History of the Market

ABSTRACT: The author shows that the history of the capitalist market is inextricably linked to an unprecedented use of force and violence in human history. Such a view of the market has a profound impact on our understanding of the transition from the feudal to the capitalist order. The author indicates that this transition was not a "liberation" from feudal bondage, but on the contrary was connected with the subordination of the market to capitalist imperatives of production. This subordination resulted not from technological progress or almost transhistorical rights, but from the transformation of social property relations between the peasants and the nobility in England. Such an approach to the capitalist market also sheds a different light on its possible political alternatives.

KEYWORDS: capitalism, market, history, Brenner, Polanyi. 